DOC.

D101,60/2:

1714 1114

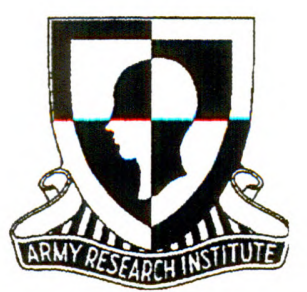

U.S. Army Research Institute for the Behavioral and Social Sciences

Research Report 1714

\title{
Preliminary Evaluation of the Computer-Based Tactics Certification Course--Principles of War Module
}

\author{
Robert J. Pleban \\ Jamye B. Brown \\ and \\ Mike T. Martin \\ U.S. Army Research Institute
}

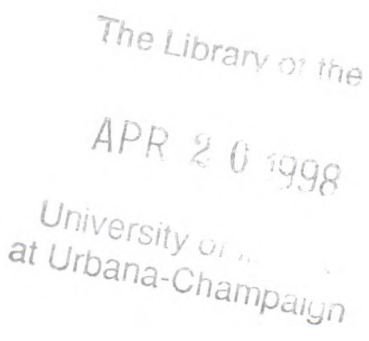

July 1997

Approved for public release; distribution is unlimited. 